\title{
Characterization of eighteen novel microsatellite markers and multiplex PCR protocol for Fagus sylvatica
}

\section{Journal Article}

Author(s):

Pluess, Andrea R.; Määttänen, Kirsti

Publication date:

2013-06

Permanent link:

https://doi.org/10.3929/ethz-b-000066082

Rights / license:

In Copyright - Non-Commercial Use Permitted

Originally published in:

Conservation Genetics Resources 5(2), https://doi.org/10.1007/s12686-012-9791-6 


\title{
Characterization of eighteen novel microsatellite markers and multiplex PCR protocol for Fagus sylvatica
}

\author{
Andrea R. Pluess • Kirsti Määttänen
}

Received: 21 September 2012/ Accepted: 28 September 2012/Published online: 6 October 2012

(C) Springer Science+Business Media Dordrecht 2012

\begin{abstract}
Eighteen novel microsatellite markers for European Beech, Fagus sylvatica, were developed using next-generation sequencing technique. Subsequently, four multiplex PCRs were established for the fast and costeffective use of the primers. In 60 individuals, we found 3-12 alleles per locus, an expected and observed heterozygosity of $0.445-0.821$ and $0.250-0.867$, respectively. Fixation index was significant in three loci. Yet, if these measures were jointly estimated with the probability of null alleles, these loci and an additional two indicated low occurrence of null alleles while the overall fixation index was non-significant. The loci were not in linkage disequilibrium. Overall, these markers will be useful for population genetic research to support management decisions for the preservation of this species in changing environmental conditions.
\end{abstract}

Keywords European beech · Fagaceae - nSSR · Population genetics

\section{Introduction}

The distribution range of Fagus sylvatica (Fagaceae), a nowadays widespread forest tree, is expected to shrink drastically due to climate change (Meier et al. 2011) as this species is vulnerable to long drought periods, a forecasted weather change (European Environmental Agency 2004). Recent studies showed adaptive variation to water availability (Rose et al. 2009; Pluess and Weber 2012) suggesting that pre-adaptive genetic variation might be available for a continuation of beech stands. To assess its micro-evolutionary potential, a thorough understanding of its gene exchange across landscapes is needed. Therefore, we established 18 novel microsatellite loci while other authors recently re-evaluated loci of the literature and also developed some new ones (Lefevre et al. 2012).

Fagus sylvatica is a diploid, wind-pollinated, mainly outcrossing (Merzeau et al. 1994) tree with primarily gravity dispersed nutlets. The generation time is $>40$ year (Hess et al. 1967) limiting its evolutionary potential to rapid changes. For its conservation, there is a call for the development of seed transfer guidelines and gene reserves (von Wuehlisch 2008).

Leaf genomic DNA was extracted from 60 individuals originating from three regions of Switzerland with two stands per region (Table 1) using DNeasy-Plant Mini and 96 Kits (Qiagen, Venlo, The Netherlands). A microsatellite enrichment library was created by "ecogenics" (Zürich, Switzerland) on a Roche 454 Genome Sequencer FLX using the Titanium Sequencing Kit (Roche Life Sciences, Branford, CT, USA). A total of 842 reads with microsatellite inserts were found with a tailor-made software (property of ecogenics) of which 161 were suitable for primer design. A total of 36 primer pairs were screened using $\geq 7$ individuals per region. Amplifications were
A. R. Pluess $(\bowtie) \cdot$ K. Määttänen

Department of Environmental Systems Science, Swiss Federal Institute of Technology (ETH Zurich), Universitaetstrasse 16, 8092 Zurich, Switzerland e-mail: andrea.pluess@env.ethz.ch 
Table 1 Origins of the Fagus sylvatica individuals for the development of the nSSR protocol including the numbers of individuals used $(N)$

\begin{tabular}{llllll}
\hline Region & Stand & Latitude & Longitude & $\begin{array}{l}\text { Elevation } \mathrm{m} \\
\text { a.s.l. }\end{array}$ & $N$ \\
\hline BAE & $\mathrm{Bfl}$ & $47^{\circ} 23^{\prime} 31.30^{\prime \prime} \mathrm{N}$ & $7^{\circ} 27^{\prime} 45.06^{\prime \prime} \mathrm{E}$ & 700 & 10 \\
$\mathrm{BAE}$ & $\mathrm{Bti}$ & $47^{\circ} 23^{\prime} 29.40^{\prime \prime} \mathrm{N}$ & $7^{\circ} 27^{\prime} 03.77^{\prime \prime} \mathrm{E}$ & 670 & 10 \\
NEU & $\mathrm{NeN}$ & $47^{\circ} 41^{\prime} 10.09^{\prime \prime} \mathrm{N}$ & $8^{\circ} 31^{\prime} 52.22^{\prime \prime} \mathrm{E}$ & 570 & 10 \\
$\mathrm{NEU}$ & $\mathrm{NeS}$ & $47^{\circ} 40^{\prime} 56.22^{\prime \prime} \mathrm{N}$ & $8^{\circ} 31^{\prime} 37.43^{\prime \prime} \mathrm{E}$ & 530 & 10 \\
VET & $\mathrm{Vfl}$ & $46^{\circ} 15^{\prime} 06.23^{\prime \prime} \mathrm{N}$ & $7^{\circ} 17^{\prime} 01.36^{\prime \prime} \mathrm{E}$ & 1280 & 10 \\
VET & $\mathrm{Vti}$ & $46^{\circ} 15^{\prime} 02.68^{\prime \prime} \mathrm{N}$ & $7^{\circ} 17^{\prime} 07.30^{\prime \prime} \mathrm{E}$ & 1200 & 10 \\
\hline
\end{tabular}

carried out in $10 \mu \mathrm{l}$ reactions with Promega reagents (Madison, WI, USA) containing $3 \mathrm{ng}$ template DNA, $1 \times$ Go Taq Flexi Buffer, $1.5 \mathrm{mM} \mathrm{MgCl} 2,0.2 \mathrm{mM}$ dNTPs, $0.04 \mu \mathrm{M}$ forward Primer with a M13 tail, $0.16 \mu \mathrm{M}$ FAM labelled M13 primer, $0.16 \mu \mathrm{M}$ reverse Primer and $0.25 \mathrm{U}$ Go Taq Polymerase using a Dyad Cycler (Bio-Rad GmbH, Vienna, Austria). Cycling conditions were: $5 \mathrm{~min}$ at $95^{\circ} \mathrm{C}$, $30 \times\left(45 \mathrm{~s}\right.$ at $95^{\circ} \mathrm{C}, 60 \mathrm{~s}$ at $55^{\circ} \mathrm{C}, 60 \mathrm{~s}$ at $\left.72{ }^{\circ} \mathrm{C}\right)$, $8 \times\left(45 \mathrm{~s}\right.$ at $95{ }^{\circ} \mathrm{C}, 60 \mathrm{~s}$ at $53{ }^{\circ} \mathrm{C}, 60 \mathrm{~s}$ at $\left.72{ }^{\circ} \mathrm{C}\right)$ and $30 \mathrm{~min}$ at $72^{\circ} \mathrm{C}$. Fragment lengths were read on an ABI3730xl and scored with GeneMapper (both AppliedBioSystems, Carlsbad, CA, USA).

The primer screening detected 18 well readable, polymorphic loci (Table 2). Four multiplex PCR reactions (M1-M4) were developed and screened using the 60 individuals. PCR conditions were the same as above despite of a $\mathrm{MgCl}_{2}$ concentration of $2.5 \mathrm{mM}$, a total volume of $12 \mu \mathrm{l}$ in M1, 0.4 and $0.48 \mathrm{U}$ of Go Taq in M1 and M4, respectively and dNTP's of $0.3 \mathrm{mM}$ in M1 and M4. See Table 2 for primer concentrations and labels. Touchdown annealing temperatures were used with seven cycles starting at $60{ }^{\circ} \mathrm{C}$ and decreasing by $1{ }^{\circ} \mathrm{C} /$ cycle followed by 30 cycles at $53{ }^{\circ} \mathrm{C}$. For the fragment analyses, $1 \mu$ of 1:5 diluted M1 and M2 products, 1:10 diluted M3 products and undiluted M4 products were used. Fingerprinting repeats $(N=12$, triple repeats) were performed in single PCR reactions.

One of the microsatellite primer pair resulted in two reads of separated lengths, thus a total of 19 loci were analyzed. The loci revealed 3-12 alleles each with an average of 6.74 ( $\mathrm{SE}=0.556$; Table 2). A hierarchical AMOVA outlined in GenALex (Peakall and Smouse 2006) indicated that populations and regions are rarely differentiated with $1 \%$ of variation explained each by differences among regions and between sites within regions $\left(P=0.055\right.$ and 0.052 , respectively). Overall expected $\left(H_{\mathrm{e}}\right)$ and observed $\left(H_{\mathrm{o}}\right)$ heterozygosity ranged from 0.445 to 0.821 and 0.250 to 0.867 , respectively (Table 2 ). The fixation index $\left(F_{\text {is }}\right)$ was significant in three loci based on $9^{\prime} 999$ permutations. Yet, if $F_{\text {is }}$ and null allele frequencies were estimated jointly in INEST (Chybicki and Burczyk 2009), these and two additional loci had low frequencies of null allele while the overall $F_{\text {is }}$ was non-significant $\left(F_{\text {is }}=0.005, \mathrm{SE}=0.004\right)$. No linkage disequilibrium among pair-wise markers was found. Successful replication frequency was 0.998 . If not otherwise stated, the estimates were calculated with FSTAT (Goudet 2001).

These novel microsatellite markers proved to be polymorphic and resulted in highly repeatable finger prints. Of the 19 microsatellite positions, 14 showed no indications for $F_{\text {is }}$ or null alleles. The remaining five might nevertheless prove to be useful in analyses independent of null alleles such as randomization tests. Overall, the development of these microsatellite markers in a multiplex PCR design will contribute to a cost-effective evaluation of genetic patterns in Fagus sylvatica. 


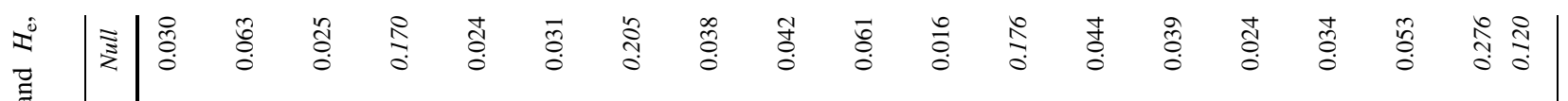

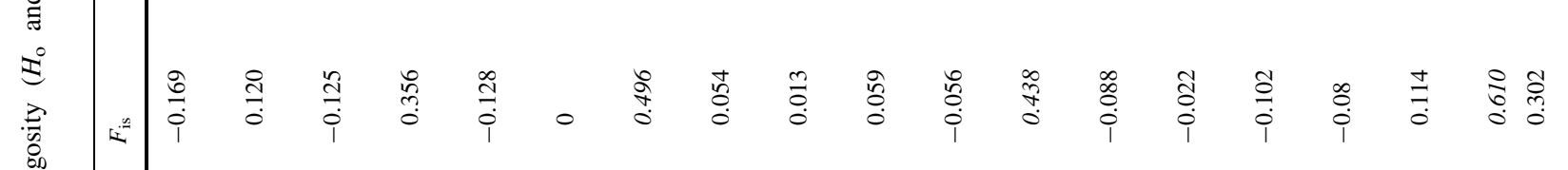
尊

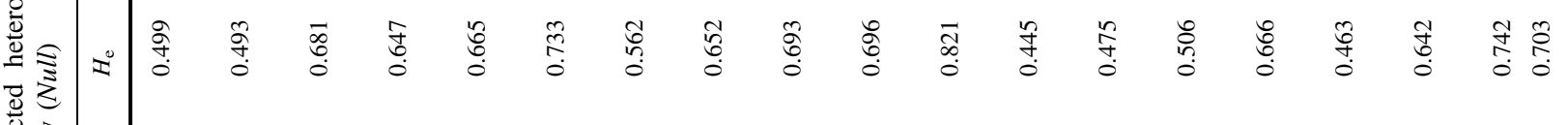

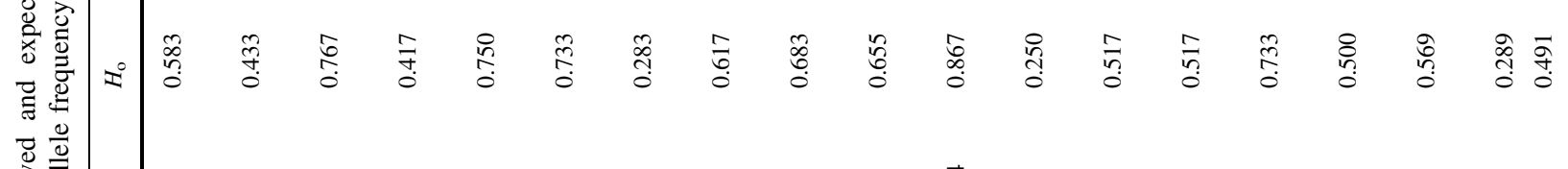

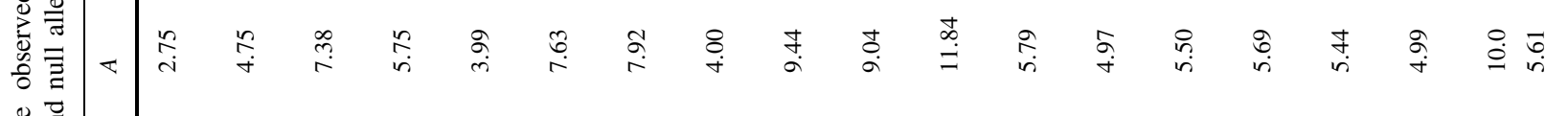

巳

s.

嵌

:

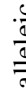

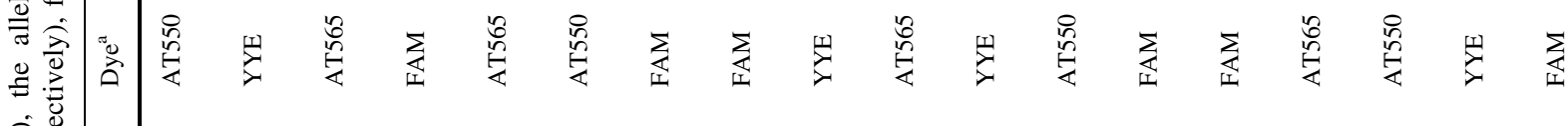

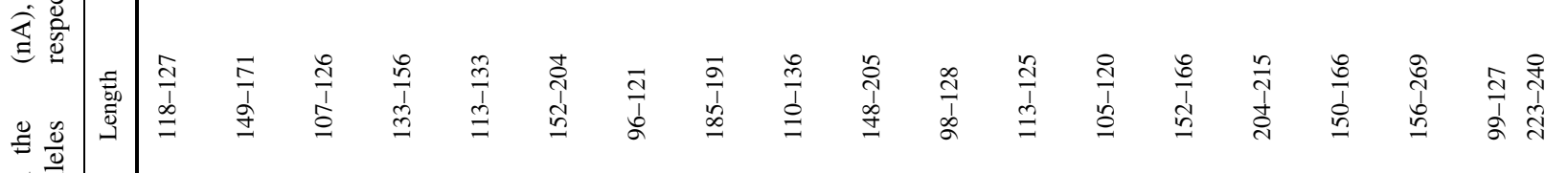

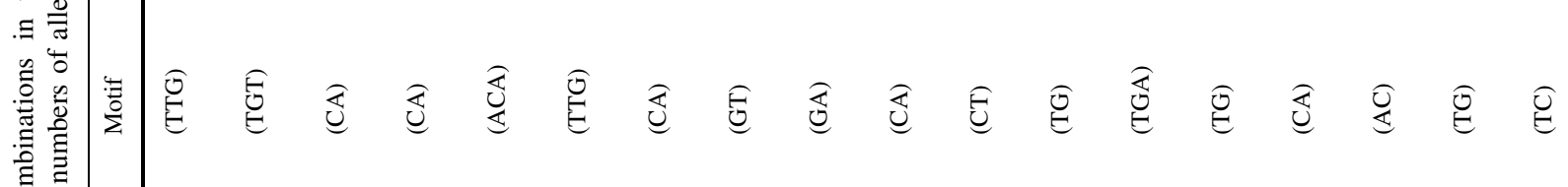
0

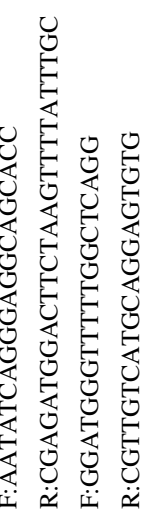


Acknowledgments The fragment analyses were done in the Genetic Diversity Center at ETH, Zurich. Financial support came from the "Fonds zur Förderung der forstlichen Forschung, ETH" (to ARP).

\section{References}

Chybicki IJ, Burczyk J (2009) Simultaneous estimation of null alleles and inbreeding coefficients. J Hered 100:106-113

European Environmental Agency (2004) Impacts of Europe's changing climate-an indicator-based assessemt, Luxembourg

Goudet J (2001) FSTAT, a program to estimate and test gene diversities and fixation indices (version 2.9.3). Available from www2.unil.ch/popgen/softwares/fstat.htm

Hess HE, Landolt E, Hirzel R (1967) Flora der Schweiz und angrenzende Gebiete, Band I. Birkhäuser Verlag, Basel und Stuttgart

Lefevre S, Wagner S, Petit RJ, de Lafontaine G (2012) Multiplexed microsatellite markers for genetic studies of beech. Mol Ecol Resour 12:484-491
Meier ES, Edwards TC, Kienast F, Dobbertin M, Zimmermann NE (2011) Co-occurrence patterns of trees along macro-climatic gradients and their potential influence on the present and future distribution of Fagus sylvatica L. J Biogeogr 38:371-382

Merzeau D, Comps B, Thiebaut B, Letouzey J (1994) Estimation of Fagus sylvatica L. mating system parameters in natural populations. Ann Des Sci For 51:163-173

Peakall R, Smouse PE (2006) GENALEX 6: genetic analysis in excel. Population genetic software for teaching and research. Mol Ecol Notes 6:288-295

Pluess AR, Weber P (2012) Drought-adaptation potential in Fagus sylvatica: linking moisture availability with genetic diversity and dendrochonology. PLoS ONE 7:e33636

Rose L, Leuschner C, Kockemann B, Buschmann H (2009) Are marginal beech (Fagus sylvatica L.) provenances a source for drought tolerant ecotypes? Eur J For Res 128:335-343

von Wuehlisch G (2008) EUFROGEN Technical Guidlines for genetic conservation and use for European beech (Fagus sylvatica), 6. Bioversity International, Rome 